[Research Paper]

\author{
소방공무원 심신안정을 위한 기능성 콘텐츠 적합성 평가 \\ 박태희 · 권진석 ${ }^{*} \cdot$ 김수영 ${ }^{* *}$ 장민혁 ${ }^{* *}$ - 김치중 ${ }^{* * *} \cdot$ 이지향 ${ }^{* \dagger}$ \\ 국립소방연구원 대응기술연구실 연구원, ${ }^{*}$ 국립소방연구원 대응기술연구실 연구사, \\ **대구테크노파크 대구과학기술진흥센터 주임연구원, ${ }^{* * *}$ 전자기술연구원 책임연구원, ${ }^{* * * *}$ 전자기술연구원 연구원,
}

\title{
Suitability Assessment of the Functional Content Platform for Stress Reduction in Firefighters
}

\author{
Tae-Hee Park $\cdot$ Jin-Suk Kwon ${ }^{*} \cdot$ Su-Young Kim ${ }^{* *} \cdot$ Min-huyk Chang ${ }^{* * *}$. \\ Chi-Jung $\mathrm{Kim}^{* * * *} \cdot \mathrm{Ji}-\mathrm{Hy}$ ang Lee (*† $^{*+}$
}

Researcher, Fire Technology Research Division of National Fire Research Institute, *Official Researcher, Fire Technology Research Division of National Fire Research Institute,

${ }^{* *}$ Assistant Researcher, Daegu Technopark Daegu Science \& Technology Promotion Center, ${ }^{* * *}$ Principal Researcher, Korea Electronics Technology Institute,

${ }^{* * * *}$ Researcher, Korea Electronics Technology Institute

(Received May 12, 2021; Revised June 10, 2021; Accepted June 11, 2021)

\section{요 약}

소방공무원은 각종 재난 현장의 위험에 항시 노출되어 있으며, 소방공무원의 정신과 신체적 건강에 대한 안전 대 책이 필요한 실정이다. 소방공무원의 정신적 스트레스를 최소화하고 정신질환을 예방하기 위해 다양한 프로그램들 이 운용되고 있으며, 심신안정실 또한 일선 소방관서에 구축하는 추세이나 아직까지 보급이 미흡한 실정이다. 이에 본 연구에서는 소방공무원 스트레스 감소를 위해 영상장치, 힐링체어, 방향 장치 등으로 구성된 독립 부스 형태의 힐링룸을 구축하여 소방관서에 배치 - 운용하였다. 본 장치는 스트레스 감소 효과를 검증하기 위해 소방공무원을 대 상으로 운용하였으며 소방공무원의 $\mathrm{ECG}$ 측정을 통해 정량적인 지표를 5 종 설정하고, 해당 지표들을 통해 스트레스 감소 효과를 확인하였다. 또한 정신건강 인터뷰를 통해 소방공무원의 스트레스를 측정 분석하여 해당 콘텐츠의 스트 레스 감소를 확인하였다. 본 연구를 통해 소방공무원의 정신적 회복탄력성 강화 및 소방관서 내 심신안정실 활성화 에 필요한 기초자료로 활용될 것으로 기대된다.

\section{ABSTRACT}

Firefighters are constantly exposed to dangers in disaster sites and they need a plan to safeguard their mental health. There are various programs in place, such as mental and physical health stabilization rooms, to reduce stress and prevent mental illnesses. While these are easily accessible during work, they are lacking in function. To effectively decrease the stress of firefighters, a 65-inch TV set, a healing chair, and an aromatic device were installed in an independent booth, called a healing room. Such rooms were built in fire stations and its effects on stress were analyzed. Five quantitative indicators were identified based on the ECG measurement of firefighters and stress reduction effects were confirmed. Additionally, for the qualitative analysis, mental health interviews of firefighters confirmed stress reduction. The results of this study are expected to be used as baseline data to enhance psychological resilience in firefighters and to revitalize their mental and physical health using stabilization rooms.

Keywords : A functional content platform, A firefighter, Stress, Electrocardiogram, Mental health interviews

\footnotetext{
${ }^{\dagger}$ Corresponding Author, TEL: +82-41-559-0551, FAX: +82-41-541-1108, E-Mail: khj2652@korea.kr

(c) 2021 Korean Institute of Fire Science \& Engineering. All right reserved.
} 


\section{1. 서 론}

소방청 통계 연보에 따르면 2019년 화재 40,103건, 구조 활동은 837,628건, 구급활동은 2,929,994건으로 나타났으며, 이에 따른 순직자 705 명, 공상자 697명으로 나타났다. 소방 공무원들은 각종 재난 현장의 위험에 항시 노출되어 있어 소방공무원의 정신과 신체적 건강에 대한 안전장치가 필요 한 실정이다 ${ }^{(1)}$.

외상후 스트레스(post traumatic stress disorder, PTSD)와 우울증을 경험하고 있는 소방공무원의 수는 지속해서 증가 하고 있다. 2020년 전국 소방공무원 마음건강 전수 조사 결 과(2)에서 조사대상자 $47.9 \%(24,977$ 명 $)$ 가 PTSD, 우울증, 수 면장애, 음주습관장애 중 적어도 하나 이상의 위험군인 것 으로 나타났으며, 치료를 해야 하는 위험군은 $13.6 \%$ (7,092명) 로 소방공무원에 대한 정신건강 관리가 필요한 것으로 나 타났다.

소방청에서는 소방공무원의 업무상 스트레스로 발생하 는 정신적 문제를 예방하기 위해 우울증, 수면장애 등을 자 가 진단하고 치료 방법을 안내하는 애플리케이션을 보급하 였으며, ‘안심 프로그램' 등 전문의와 상담·치료를 연계하 는 다양한 심리프로그램을 추진 중이다. 또한 소방서 내 심 신안정실의 보급·확대를 위해 소방정책의 성과 측정지표 로 소방본부 역량에 심신안정실 설치율을 평가하였다(). 그 러나 소방공무원이 업무 현장에서 쉽게 접할 수 있는 심신 안정실은 지역별 설치율의 편차가 크며, 소방공무원의 육 체적 - 신체적 스트레스를 낮춘다는 본래의 목적과 다르게 활용되는 경우가 많다(4).

또한 심신안정실 내 한정된 콘텐츠들로 인해 사용자들 의 기대심리가 낮아져 사용 빈도가 감소하였으며, 계급구 조의 직장문화로 인하여 자유로운 사용이 어려운 것으로 나타났다.

이에 본 연구에서는 단계별 연구수행을 통해 소방공무 원 스트레스 감소를 위한 콘텐츠를 기획 - 도출하였다. 먼 저 virtual reality (VR) 콘텐츠와 사용자의 뇌파- 맥파를 측 정할 수 있는 기기가 포함된 '이동식 심신안정실'을 구축 운용함으로써 신규 콘텐츠 도입에 필요한 사항을 도출하였 다. 다음으로 내 - 외 선행연구 조사를 통해 스트레스 감소 를 위한 최적 콘텐츠를 도출·적용하였다(5).

소방에 특화된 스트레스 감소 콘텐츠(기능성 콘텐츠)를 개발하기 위해 기존 VR을 이용한 콘텐츠 플랫폼의 단점을 개선하고, 기능성 콘텐츠 플랫폼을 소방현장에 도입하기 위해 국내·외 문헌들을 검토하였다.

국내 논문 중 $\mathrm{Kim}$ 과 $\mathrm{Cho}^{(6)}$ 의 연구에 따르면 영상과 소리 를 통해 사용자의 스트레스에 영향을 줄 수 있다고 발표하 였으며, Chun 등(7)은 간단한 텔레비전 영상이 스트레스 감 소에 효율적이라고 직무 스트레스 측정 도구를 통해 정성 적으로 분석하였다. $\mathrm{Oh}$ 와 $\mathrm{Park}^{(8)}$ 은 환경조건으로 영상과 후각을 실제 환경과 유사하게 자극하는 경우 심박변이도를
통해 정량적 스트레스 반응 분석이 가능하다고 밝혔다. 국외 논문 중 Nadkarni 등(9)은 자연환경을 접하기 어려운 교도소 수감자들에게 자연 영상을 보여 준 후 스트레스 감소 에 따른 폭력성이 $26 \%$ 감소하였다고 밝혔으며, Ahmaniemi 등(10) 은 또한 직장에서 스트레스를 받는 사람에게 차분한 소리와 음악이 들리는 화면을 보여주었을 때 스트레스 지표인 심박 수가 현저히 낮아진다는 것을 확인하였다. Brooks 등(11)은 자 연 접촉에 따른 사용자의 불안과 우울증을 표준화된 설문지를 통해 정성적으로 분석하였으며, 자연환경을 나타내는 이미지 나 영상을 통해서도 스트레스 완화 효과가 있다고 밝혔다.

최근 기술의 발전으로 가상현실, 증강현실, 혼합현실 등 다양한 플랫폼이 개발되고 있으며, 사용자의 스트레스 감 소 등 다양한 목적을 가진 기능성 콘텐츠들이 개발되고 있 다. 그러나 일반적 사용자를 주 대상으로 하고 있으며, 업 무 위험성이 높은 소방공무원에 대한 콘텐츠 개발은 미비 한 실정이다.

따라서 본 연구에서는 소방관서 심신안정실 내 독립 부스 (힐링룸)를 구축하여 소방공무원의 자기 명상(self meditation) 과 몰입도 높은 자연 영상 콘텐츠를 통해 소방공무원의 스 트레스 감소 효과를 검증하고자 하였다.

\section{2. 연구방법 및 시작품 구축}

본 연구에서는 콘텐츠의 효과성 검증을 위해 정량적 분 석과 정성적 분석을 실시하였다. 정량적 분석은 심박변이 도를 기준으로 측정하였으며, 정성적 분석은 일반적으로 사용되는 정신건강 측정 도구를 인용한 인터뷰를 통해 측 정하였다.

소방공무원의 스트레스 감소를 목표로 국립소방연구원 과 전자기술연구원이 협업하여 본 연구를 수행하였다. 국 립소방연구원에서는 콘텐츠 시나리오 기획, 대상 소방관서 선정, 만족도 평가, 정성적 분석을 실시하였으며, 전자기술 연구원에서는 기능성 콘텐츠 플랫폼 구축 및 정량적 분석 을 수행하였다.

\section{1 대상지 선정}

본 연구는 전라남도에 있는 소방관서 1 개소를 대상으로 콘텐츠 실증 실험하였다. 대상지의 경우 최근에 건축된 관 서로 심신안정실 내부에 별도의 장비 - 콘텐츠 없이 공간만 구축되어 있어 힐링룸 설치가 쉽고, 평상시 심신안정과 관 련된 콘텐츠가 없어 신규 콘텐츠 적용 시 스트레스 감소 정도가 크게 작용할 것으로 판단되었다. 또한 대상지의 업 무 특성상 소방헬기의 운용이 많고 대형 재난에 투입됨에 따라 일선 시 · 도 관서의 소방공무원보다 큰 강도의 스트 레스 환경에 노출되어 있어 본 대상지를 선정하게 되었다.

대상 소방관서의 총원은 40 명이며(실험 시점 기준) 그중 35 명 $(87.5 \%)$ 의 소방공무원을 대상으로 2020 년 11 월 25 일부 터 11월 27일까지 3일 동안 실증실험을 진행하였다(Table 1). 
Table 1. The Population Characteristics

\begin{tabular}{|c|c|c|c|}
\hline \multicolumn{2}{|r|}{ Categories } & Population & $\%$ \\
\hline \multirow{2}{*}{ Sex } & Male & 35 & 100 \\
\hline & Female & 0 & 0.0 \\
\hline \multirow{4}{*}{ Age } & 20 's & 3 & 8.6 \\
\hline & 30 's & 9 & 25.7 \\
\hline & 40 's & 16 & 45.7 \\
\hline & 50 's (or more) & 7 & 20.0 \\
\hline \multirow{6}{*}{ Rank } & A fire man & 4 & 11.4 \\
\hline & A senior fireman & 4 & 11.4 \\
\hline & A fire sergeant & 7 & 20.0 \\
\hline & A fire lieutenant & 4 & 11.4 \\
\hline & A fire captain (or more) & 6 & 17.1 \\
\hline & A professional career officer & 10 & 28.6 \\
\hline \multirow{3}{*}{$\begin{array}{l}\text { Service } \\
\text { career }\end{array}$} & less than 10 years & 10 & 28.6 \\
\hline & 10 to 20 years & 11 & 31.4 \\
\hline & more than 20 years & 14 & 40.0 \\
\hline
\end{tabular}

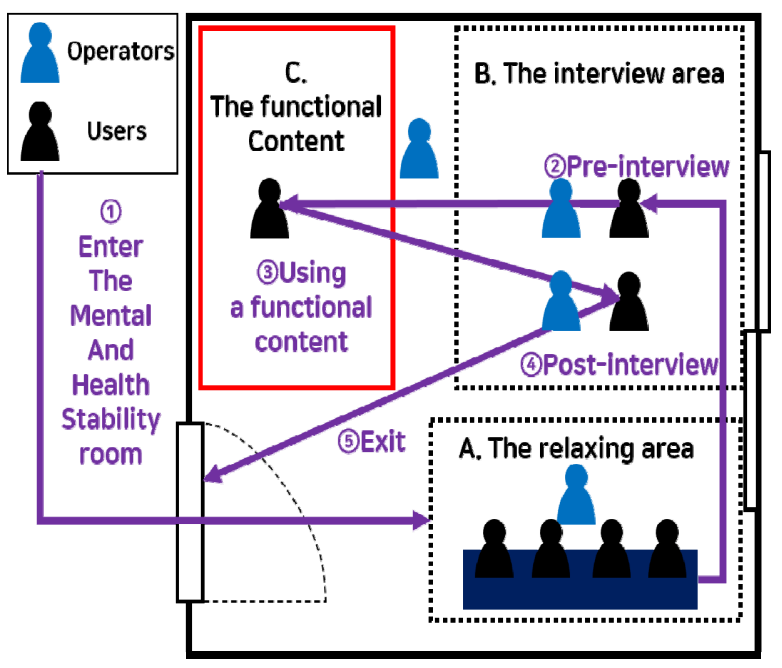

Figure 1. The process of functional contents platform.

\section{2 실증운영 프로세스}

실증운영은 $\mathrm{A}, \mathrm{B}, \mathrm{C}$ 총 3 구역, 5 단계의 진행, 4 명의 운영 자로 구성하였다. A.대기 공간의 경우 체험자들에게 기능 성 콘텐츠(이하 힐링룸)에 대한 설명과 체험 참여자의 심신 안정화를 주목적으로 하였으며, B.인터뷰공간의 경우 힐링 룸 사용 전 - 후 인터뷰를 진행하는 공간으로 구분하였다. C.힐링룸의 경우 사용자가 직접 콘텐츠를 체험하는 장소로 음성안내에 따른 명상과 스트레스 완화를 위한 콘텐츠를 체험하는 곳으로 구성하였다(Figure 1).

\section{3 기능성 콘텐츠 플랫폼 개요}

기능성 콘텐츠 플랫폼의 하드웨어 구축은 전자기술연구 원에서 전담하였으며, 콘텐츠 운용 중 외부로부터의 방해와
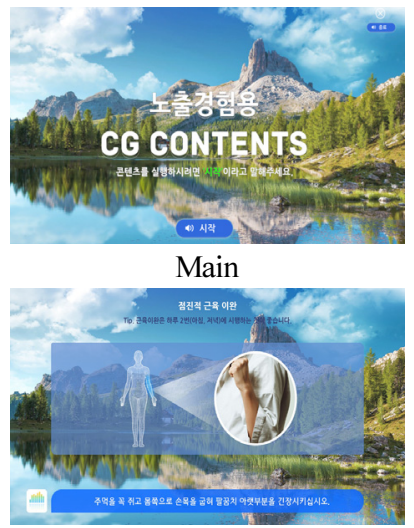

Muscle relaxation

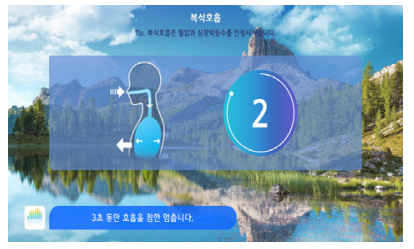

Abdominal breathing

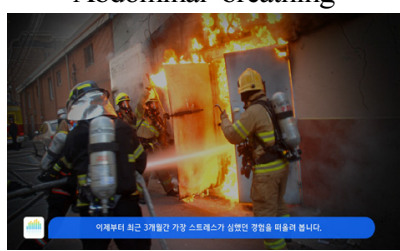

Self meditation
Figure 2. The program of the functional content.

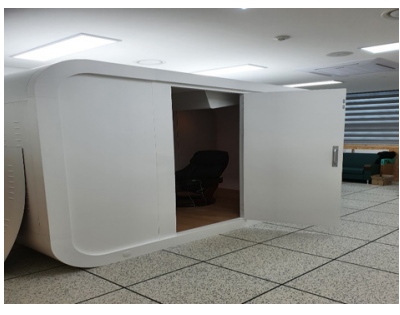

The exterior

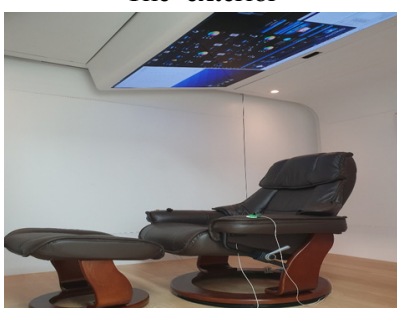

The healing chair

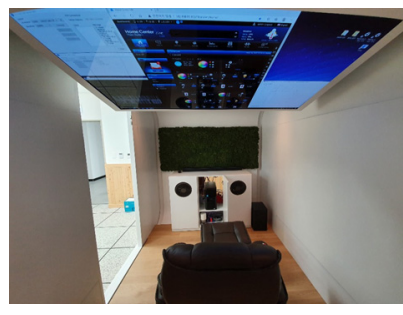

The interior

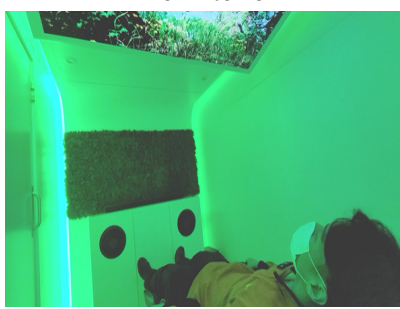

Watching the healing content
Figure 3. The functional content platform program.

의도치 않은 반응을 차단하기 위해 독립 부스로 제작되었다.

힐링룸은 $\mathrm{W}: 3,500 \mathrm{~mm} \times \mathrm{L}: 2,000 \mathrm{~mm} \times \mathrm{H}: 2,100 \mathrm{~mm}$ 로 부피 약 $14.7 \mathrm{~m}^{3}$ 로, 사용자의 편안한 명상과 감상을 위해 힐링체어를 중앙에 배치하였으며, 천장부에는 안내 영상과 자연 영상을(Figure 2) 시청할 수 있는 65 in 텔레비전이 부 착되었다.

의자 전면부에는 사용자에게 영상 주제에 맞는 향과 바 람을 느낄 수 있는 방향 장치와 풍향 장치, 내부 조명을 설 치하여 몰입감 높은 영상시청이 가능하도록 하였다(Figure 3). 또한 힐링의자에 체험자의 손바닥과 검지, 중지에서 생체 신호를 측정할 수 있는 무자각형 접촉식 센서를 부착하여 스트레스 관련 지표 추출이 가능한 심전도(ECG)와 피부전 도도(GSR)를 측정하였다(Figure 4).

\section{4 정량적 스트레스 측정방안}

기능성 콘텐츠는 기억 회상과 스트레스 감소 작용 2 단계 로 구성되었다. 먼저 1 단계에서는 소방공무원의 자기 명상 을 통해 소방 활동 현장에서의 아픈 기억을 회상하고, 2 단 

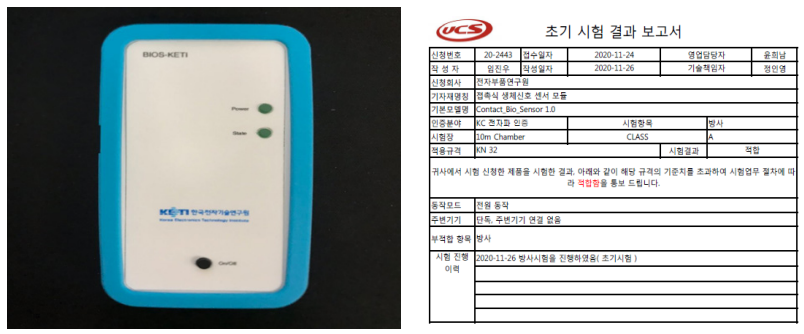

The sensor module (ECG) Electromagnetic wave test $(\mathrm{KC})$

Figure 4. The module for measuring ECG.

계에서 편안한 자연 감상으로 해당 기억에 대한 스트레스 촉발 반응을 줄여나가는 원리이다(Figure 5).

힐링룸에 입장하여 편안한 자세를 취한 후 소방공무원 의 심리적 안정화를 위해 약 $2 \mathrm{~min}$ 동안 복식호흡을 하며 심전도(electrocardiogram, ECG), 피부 전도도(GSR) 레퍼런 스 신호를 측정하였으며, 점진적 근육 이완으로 안정화 상 태로 이끌었다.

다음으로 약 $1 \mathrm{~min}$ 간의 노출을 상기하는 명상을 진행하 면서 사용자의 스트레스 $\mathrm{ECG}, \mathrm{GSR}$ 신호를 측정하고, 자연 영상을 감상할 수 있는 힐링 콘텐츠를 $3 \mathrm{~min}$ 간 시청함으로써 $\mathrm{ECG}, \mathrm{GSR}$ 변화를 재측정하였다(Figures 2, 3). ECG, GSR 측정을 통해 콘텐츠 운용 전 - 후에 변화하는 스트레스 지 표를 선정하고 해당 지표에 대한 측정값을 비교 - 분석하였 다. 지표 측정값에 대한 해석은 $\mathrm{Oh}$ 와 $\mathrm{Park}^{(8)}$ 의 연구에서 사 용한 '심박변이도(heart rate variability, HRV) 지표의 의미와 임상적 해석'을 참고하였다.

\section{5 정성적 스트레스 측정방안}

소방공무원의 정성적 스트레스 측정을 위해 기능성 콘 텐츠 사용 전과 후 2회에 걸쳐 인터뷰를 수행하였으며, 인 터뷰 결과는 통계프로그램(SPSS)을 통해 분석하였다.

인터뷰 내용으로는 정신건강 분석에서 자주 사용되는 해밀톤 우울 등급 척도(hamilton depression rating scale, $\mathrm{HDRS}$ )와 백 불안 척도(beck anxiety inventory, BAI)를 인용 하였으며, 결과는 사전 - 후 정신건강 지수의 변화에 대해 통계적으로 처리하였다. 통계 처리는 SPSS 25.0을 사용하 여 정성적 - 정량적 효과분석을 하였으며, 결과값의 대응 표본 T-검정을 통해 기능성 콘텐츠의 소방공무원 스트레스 감소 효과를 분석하였다.
Table 2. The Meaning and Clinical Interpretation of HRV

\begin{tabular}{c|l}
\hline \multicolumn{2}{c}{ Category } \\
\hline \hline $\begin{array}{c}\text { Total Power } \\
\text { (TP) }\end{array}$ & $\begin{array}{l}\text { In case of chronic stress or illness, TP } \\
\text { decreases significantly compared to healthy } \\
\text { conditions due to a decrease in autonomic } \\
\text { nervous system regulation ability. }\end{array}$ \\
\hline $\begin{array}{c}\text { Low frequency } \\
\text { (LF) }\end{array}$ & $\begin{array}{l}\text { When a human's bioenergy is lost, LF } \\
\text { decreases. }\end{array}$ \\
\hline $\begin{array}{c}\text { High frequency } \\
\text { (HF) }\end{array}$ & $\begin{array}{l}\text { HF is low for patients suffering from persistent } \\
\text { stress, fear, anxiety or heart disease. }\end{array}$ \\
\hline $\begin{array}{c}\text { Standard } \\
\text { deviation of } \\
\text { NN intervals } \\
\text { (SDNN) }\end{array}$ & $\begin{array}{l}\text { The lower SDNN, the loss of a automatic } \\
\text { nervous system homeostasis mechanism for } \\
\text { changes in the body and the external } \\
\text { environment. }\end{array}$ \\
\hline $\begin{array}{c}\text { Root mean } \\
\text { square of } \\
\text { successive }\end{array}$ & $\begin{array}{l}\text { RMSSD is involved in the electrical stability } \\
\text { of the heart, The people feel stress is lower } \\
\text { RR interbval } \\
\text { differneces } \\
\text { (RMSSD) }\end{array}$ \\
\hline $\begin{array}{c}\text { Galvanic skin } \\
\text { response } \\
\text { (GSR) }\end{array}$ & $\begin{array}{l}\text { GSR is a measure of skin's sweat emissions } \\
\text { and body temperature changes, which } \\
\text { indicates that the higher the value, the mosre } \\
\text { stressed it is. }\end{array}$ \\
\hline
\end{tabular}

\section{3. 심신안정실 기능성 콘텐츠 실증결과}

\section{1 사용자의 일반적 특성}

피실험자 35 명 전원 남성으로 나이로는 '40대'가 16 명 $(45.7 \%)$, 계급으로는 '전문 경력관'이 10 명(28.6\%)로 가장 많았으며, 근무경력으로는 '20년 이상'이 14명(40.0\%)으로 가장 많았다.

실증에 참여한 소방공무원은 일반적으로 현장경험과 현장 경력이 높은 구조 분야를 담당하고 있는 것으로 나타났다.

\section{2 정량적 스트레스 분석결과}

정량분석에 앞서 소방공무원의 스트레스 지표 10 종에 대한 평가 분석을 통해 신뢰도수준 $p<.05$ 의 유효성 평가 를 진행하였다. 대응표본 T-검정을 통해 6종의 생체신호인 신체활성도(TP), 스트레스 저항도(SDNN), 육체 피로도(LF), 스트레스(HF), 심장건강도(RMSSD), 피부 전도도(GSR)가 소방공무원의 정량적인 스트레스 지표로 사용될 수 있는 유효변인으로 선정되었다(Table 2).

\begin{tabular}{|c|c|c|c|c|c|}
\hline Step 1. & $\begin{array}{c}\text { Step 2. } \\
\begin{array}{c}\text { The program } \\
\text { explanation \& } \\
\text { Sign a consent }\end{array}\end{array} \Rightarrow \begin{array}{c}\text { Abdominal } \\
\text { breathing \& } \\
\text { Measuring } \\
\text { ECG(Ref,) }\end{array}$
\end{tabular}$\Rightarrow \begin{gathered}\text { Step 3. } \\
\begin{array}{c}\text { Muscle } \\
\text { relaxation }\end{array}\end{gathered} \Rightarrow \begin{gathered}\text { Step 4. } \\
\begin{array}{c}\text { Selfmeditation \& } \\
\text { Measuring } \\
\text { ECG(pre) }\end{array}\end{gathered} \Rightarrow$\begin{tabular}{c}
$\begin{array}{c}\text { healing } \\
\text { content \& } \\
\text { Measuring } \\
\text { ECG(post) }\end{array}$ \\
\hline
\end{tabular}

Figure 5. The process of functional contents program. 
Table 3. The Result of Paired t-test (ECG)

\begin{tabular}{|c|c|c|c|c|c|c|c|c|c|}
\hline & & \multicolumn{5}{|c|}{ Paired differences } & \multirow{3}{*}{$\mathrm{t}$} & \multirow{3}{*}{$\mathrm{df}$} & \multirow{3}{*}{$\begin{array}{c}\text { Sig. } \\
\text { (2-tailed) }\end{array}$} \\
\hline & & \multirow{2}{*}{ Mean } & \multirow{2}{*}{$\begin{array}{c}\text { Std. } \\
\text { deviation }\end{array}$} & \multirow{2}{*}{ Std. error mean } & \multicolumn{2}{|c|}{$\begin{array}{l}95 \% \text { Confidence interval } \\
\text { of the difference }\end{array}$} & & & \\
\hline & & & & & Lower & Upper & & & \\
\hline Pair 1 & Pre-Post TP & -.531 & .937 & .177 & -.894 & -.168 & -2.999 & 27 & .006 \\
\hline Pair 2 & Pre-Post LF & -.718 & 1.409 & .266 & -1.265 & -.172 & -2.696 & 27 & .012 \\
\hline Pair 3 & Pre-Post HF & -.369 & .875 & .165 & -.708 & -.030 & -2.231 & 27 & .034 \\
\hline Pair 4 & $\begin{array}{l}\text { Pre-Post } \\
\text { SDNN }\end{array}$ & -14.597 & 29.797 & 5.631 & -26.152 & -3.043 & -2.592 & 27 & .015 \\
\hline Pair 5 & $\begin{array}{l}\text { Pre-Post } \\
\text { RMSSD }\end{array}$ & -9.993 & 21.836 & 4.127 & -18.460 & -1.526 & -2.422 & 27 & .022 \\
\hline Pair 6 & Pre-Post GSR & .500 & 2.822 & .533 & -.594 & 1.594 & .938 & 27 & .357 \\
\hline
\end{tabular}

Table 4. The Result of Paired t-test (Mental Health Interviews)

\begin{tabular}{|c|c|c|c|c|c|c|c|c|c|}
\hline & & \multicolumn{5}{|c|}{ Paired differences } & \multirow{3}{*}{$\mathrm{t}$} & \multirow{3}{*}{$\mathrm{df}$} & \multirow{3}{*}{$\underset{\text { (2-tailed) }}{\text { Sig. }}$} \\
\hline & & \multirow{2}{*}{ Mean } & \multirow{2}{*}{$\begin{array}{c}\text { Std. } \\
\text { deviation }\end{array}$} & \multirow{2}{*}{$\begin{array}{c}\text { Std. } \\
\text { error mean }\end{array}$} & \multicolumn{2}{|c|}{$\begin{array}{l}95 \% \text { Confidence interval of the } \\
\text { difference }\end{array}$} & & & \\
\hline & & & & & Lower & Upper & & & \\
\hline Pair 1 & $\begin{array}{l}\text { Pre-post } \\
\text { depression }\end{array}$ & 2.257 & 3.175 & .537 & 1.167 & 3.348 & 4.206 & 34 & .0001 \\
\hline Pair 2 & $\begin{array}{l}\text { Pre-post } \\
\text { anxiety }\end{array}$ & 1.571 & 2.266 & .383 & .793 & 2.350 & 4.103 & 34 & .0001 \\
\hline
\end{tabular}

힐링 콘텐츠 시청에 따른 스트레스 완화 효과를 분석하 기 위한 $\mathrm{ECG}$ 측정 결과의 대응표본 $\mathrm{T}$-검정 결과 '신체 활 성도(TP)'의 경우 스트레스를 받는 구간에서의 평균 $5.05 \pm$ 1.23 에서 $5.58 \pm 1.47$ 로 증가하였다 $(p<.006)$. '피로도(LF)'의 경우 스트레스를 받는 구간에서 평균 $3.86 \pm 1.39$ 에서 4.58 \pm 1.63 으로 증가하였으며 $(p<.012)$, '스트레스 $(\mathrm{HF})$ '의 경우 평균 $4.36 \pm 1.42$ 에서 $4.73 \pm 1.62$ 로 증가하였다 $(p<.034)$. '스 트레스 저항도(SDNN)'의 경우 평균 $36.90 \pm 21.66$ 에서 $51.49 \pm$ 41.72 로 증가하였으며 $(p<.015)$, '심장 건강도(RMSSD)'의 경우 평균 $39.32 \pm 26.37$ 에서 $49.31 \pm 41.92$ 로 증가하였다 $(p<$ .022). '피부 전기 전도도(SCR)'의 경우 평균값은 감소하였으 나 유의미한 변화는 나타나지 않았다 $(p<.357)($ Table 3$)$.

소방공무원의 스트레스를 $\mathrm{ECG}$ 를 통해 분석하였을 때, 총 6개의 지표 중 '피부 전도도(GSR)'을 제외한 5 개의 지표 에서 유의한 차이를 나타냈으며, 힐링 콘텐츠를 시청한 후 스트레스가 감소하는 것으로 나타났다.

\section{3 정성적 스트레스 분석결과}

힐링 콘텐츠 시청에 따른 스트레스 완화 효과를 분석하기 위한 사전 - 후 인터뷰 결과, 사전에 '우울' 경증 12 명(34.3\%), 정상 23 명 $(65.7 \%)$ 인 반면 사후의 경우 경증 6명(17.1\%), 정 상 29 명 $(82.9 \%)$ 로 나타나 힐링룸 내 콘텐츠 시청 후 우울감 이 줄어든 것으로 나타났다. ‘불안'에서는 사용 전·후 모 두 정상으로 나타났다.
Table 5. The Cronbach's $\alpha$ of the Mental Health Interviews

\begin{tabular}{ccc}
\hline \multicolumn{2}{c}{ Categories } & Cronbach's $\alpha$ \\
\hline \hline \multirow{2}{*}{$\begin{array}{c}\text { Mental } \\
\text { health }\end{array}$} & Depression & .707 \\
\cline { 2 - 3 } & Anxiety & .747 \\
\hline
\end{tabular}

해당 지표들의 결과 값을 대응표본 $\mathrm{t}$ 검정으로 분석하였 을 경우 ‘우울'의 경우 평균 $5.62 \pm 3.37$ 에서 $3.38 \pm 3.45$ 로 감소하였으며 $(p<.0001)$, '불안'의 경우 평균 $2.71 \pm 2.47$ 에서 $1.12 \pm 2.17$ 로 유의미하게 감소하였다 $(p<.0001)$ (Table 4).

소방공무원의 정성적인 스트레스 측정을 위해 사용된 인터뷰 질문지의 신뢰도 검정결과는 '우울'과 '불안' 항목 에서 신뢰할 수 있는 결과로 나타났다(Table 5).

\section{4. 결론 및 제언}

본 연구는 기존 심신안정실 내 VR 콘텐츠를 통한 소방 공무원 스트레스 감소 연구에서 도출된 VR기기 사용의 어 려움과 소음, 간섭 등 사용자의 심리적 불안감을 유발하는 외부 방해 요소를 최소화 한 기능성 콘텐츠 플랫폼을 구축 하고 실제 소방관서에 적용하여 스트레스 감소 효과성 검 증을 수행하였다. 전라남도에 위치한 소방관서의 소방공무 원 35 명을 피실험자를 대상으로 효과성을 측정하였으며, $\mathrm{ECG}$ 를 통한 심박변이도를 통한 정량적인 분석과 정신건강 
인터뷰를 통한 정성적인 분석을 수행하였다.

기능성 콘텐츠를 체험한 소방공무원의 $\mathrm{ECG}$ 측정 결과 기능성 콘텐츠 사용 후 스트레스와 연관된 심박변이도 5 종 에 대한 지표가 유의하게 변화하여, 스트레스 감소에 효과 적인 것으로 나타났다. 또한 정신건강 인터뷰를 통해 정성 적으로 측정한 ‘우울’과 ‘불안’에서도 유의미한 스트레스 감소가 관찰됨에 따라, 앞서 서론에서 언급된 선행연구들 과 유사한 결과가 도출되었다.

그러나 소방공무원의 정량적인 스트레스 분석을 위해 수행된 지표 중 하나인 '피부 전도도(GSR)'에서 스트레스 가 감소하는 경향을 나타냈음에도 유의미한 차이를 얻지 못한 것은 사용자의 움직임이나 피부에 전극이 접촉하는 정도에 따른 측정값 변동의 영향이라 판단된다. 이는 피부 전도도 측정의 시 자세로 인한 측정 오류를 주장한 $\mathrm{Kim}$ 과 $\mathrm{Yun}^{(12)}$, 센서 접촉에 따른 측정변동을 언급한 $\mathrm{Lim}$ 등(13)의 연구와 유사하게 나타났다.

따라서 본 연구에서는 소방 특화 기능성 콘텐츠 플랫폼 의 실증을 통해 소방공무원의 정량적 평가를 위한 5 종에 대한 지표를 수립하였으며, 정량적 - 정성적 분석결과 기능 성 콘텐츠가 소방공무원의 스트레스 감소에 효과적이라는 것을 확인하였다.

본 연구의 경우 소방관서 1 개소, 35 명의 피실험자를 대 상으로 효과성을 검증하였으나, 세계적으로 유행하고 있는 COVID-19의 영향으로 다수의 소방관서와 인원을 대상으 로 하지 못한 한계점이 있다.

또한, 기능성 콘텐츠의 효과성 검증을 위한 반복적 측정 부재로 추가적인 연구수행으로 기능성 콘텐츠의 정확성을 검증할 필요가 있으나, 본 연구는 소방공무원의 정신적 회 복탄력성 강화 및 소방관서 내 심신안정실 활성화에 필요 한 기초자료로 활용될 것으로 기대된다.

\section{후 기}

본 연구는 소방청 소방대응력향상을 위한 연구개발지원 사업(1761002000)의 연구비 지원을 받아 수행되었습니다.

\section{References}

1. National Fire Agency, "National Fire Agency Statistical Year Book" (2019).

2. H. W. Shin, "2020 Mental Health Survey Result Report", National Fire Agency (2020).

3. E. K. Kim, C. S. Park, Y. S. Kim, K. H. Ra, M. K. Cha and Y. J. Aum, "Basic Investigation for Research and development of Resilience for Firefighters", National Fire Science Research Center (2018).
4. J. H. Lee and T. H. Park, "Verification of Effectiveness for Firefighters Stress Reduction by the Functional Contents Platform", National Fire Research Institute (2020).

5. T. H. Park, J. H. Lee and S. Y. Kim, "Assessing the Suitability of Virtual Reality Content for Stress Reduction among Firefighters", Fire Science and Engineering, Vol. 34, No. 6, pp. 154-162 (2020). https://doi.org/10.7731/KIFSE. $46534 \mathrm{fdb}$.

6. M. S. Kim and Y. C. Cho, "GSR, HRB and EEG Analysis of Stress Caused by Horror Image and Noise Stimulation", Institute of Korean Electrical and Electronics Engineers, Vol. 21 No. 4, pp. 381-387 (2017). https://doi.org/10.7471/ ikeee.2017.21.4.381.

7. K. J. Chun, S. O. Lee, Y. R. Kim and S. S. Kim, "The Effects of Watching TV Programs on Employees Stress and Communication", Journal of the Korea Contents Association, Vol. 18, No. 12, pp. 394-404 (2018). https://doi.org/10. 5392/JKCA.2018.18.12.394.

8. J. Y. Oh and H. K. Park, "Analysis of Previous Research on Heart Rate Variability and Stress Response by Environmental Stimulation", The Korean Society of Science \& Art, Vol. 38, No. 2, pp. 231-241 (2020). https://doi.org/10.17548/ ksaf. 2020.03.30.231.

9. N. M. Nadkarni, P. H. Hasbach, T. Thys, E. G. Crockett and L. Schnacker, "Impacts of Nature Imagery on People in Severely Nature-deprived Environments", Frontiers in Ecology and the Environment, Vol. 15, No. 7, pp. 395-403 (2017). https:// doi.org/10.1002/fee.1518.

10. T. Ahmaniemi, H. Lindholm, K. Muller and T. Taipalus, "Virtual Reality Experience as a Stress Recovery Solution in Workplace", IEEE Life Sciences Conference (LSC), pp. 206-209 (2017). https://doi.org/10.1109/LSC.2017.8268179.

11. A. M. Brooks, K. M. Ottley, K. D. Arbuthnott and P. Sevigny, "Nature-related mood effects: Season and type of nature contact", Journal of Environmental Psychology, Vol. 54, pp. 91-102 (2017). https://doi.org/10.1016/j.jenvp.2017. 10.004 .

12. D. Y. Kim and S. S. Yun, "Numerical Analysis of Stressful Stimuli based on the Galvanic Skin Response", The Korea Institute of Information and Communication Engineering, Vol. 23 No. 2, pp. 113-115 (2019).

13. T. G. Lim, J. H. Heo, K. W. Jeong and H. H. Ghim, "Stress Assesment based on Bio-Signals using Random Forest Algorithm", Journal of the Korean Society of Safety, Vol. 35, No. 1, pp. 62-69 (2020). https://doi.org/10.14346/JKOSOS. 2020.35.1.62. 